\title{
RESEARCH ON THE IMPROVEMENT OF INDUSTRIAL PRACTICES OF TRANSPORT AND LOGISTICS STUDENTS: CASE STUDY IN LITHUANIA
}

\author{
Kristina ČIŽIŪNIENĖ, Nijolè BATARLIENE ${ }^{*}$ \\ Dept of Logistics and Transport Management, Vilnius Gediminas Technical University, Lithuania
}

Received 30 September 2017; revised 7 March 2018; accepted 17 April 2018

\begin{abstract}
The article examines the impact of human resource practices on future employees in the transport and logistics sector where logistics companies operate. It presents the impact of the organization and implementation of industrial practices on the preparation of young specialists in the transport and logistics sectors and self-actualization of students. A research was conducted revealing how each industrial practice is actually perceived and accepted by a trainee, the industrial practice supervisor of a school of higher education and persons responsible for industrial practices in companies at the organizational level. The article also presents the expert assessment method and calculations of the compatibility of expert opinions. The obtained research results allowed developing a hypothetical model for the organization and implementation of the industrial practice process, which lists conditions for organizing and implementing industrial practices and potential results associated with the improvement of competencies, self-actualization of young specialists and concordance with study results.
\end{abstract}

Keywords: industrial practices, transport/logistics sector, young specialist, graduates, experts.

\section{Introduction}

In the modern world, logistics plays a significant role in the activities of a business unit; it includes each actor in the supply chain. The growing globalization leads to increasingly shortening development and life cycles of new produce. Consumers seek for the necessary produce to reach them in a short period at the lowest possible cost. For this reason, logistics solutions must not only ensure accurate implementation of goals of a business unit, but also find the optimal and most cost-effective ways to achieve this. Business logistics can be defined as a group of inter-related areas of activities managed in a coordinated manner, the main task whereof is to supply consumers with goods or services in the most efficient manner, considering their needs and the existing demand. However, companies operating in the logistics sector face one of the key problems of the sector, mainly, a high employee turnover rate, dishonest and irresponsible employees, and yet another important business challenge - improvement of productivity of employees and service quality. For this reason, effective and correct management of human resources is seen as one of measures to reduce employee turnover and achieve goals of operations. On the other hand, practical preparation of employees for work is also an important aspect. Attitude of employees can not only improve or deteriorate the team's approach to work (the attitude has a chain reaction), but may also have a significant impact on productivity, honesty, responsibility, etc.

Literature does not have any common agreement on a uniform list of human resource practices and their direct impact on activities of the organization (Torrington et al. 2010; Noe et al. 2016; Fisher et al. 2003; Dessler 2016; Price 2007, etc.).

Academic literature intensively discusses different human resource practices and their relation to the company's activities. Researchers have been analysing information on human resource management for a long time, with the aim to understand the relation between human resource practices and operating results of enterprises (Delery, Doty 1996; Huselid 1995, etc.). A lot of empirical research reviews related to the topic can be found in literature, but the majority concludes that research conducted in the past shows a different positive relation between practices and

${ }^{*}$ Corresponding author. E-mail: nijole.batarliene@vgtu.lt 
financial results of the company. Still, there is almost no research conducted in order to identify processes, which lead to this impact, because the majority of previous research of management of human resources and operations examined human resource management practices in combination.

Human resources are one of the most important factors that create added value in transport and logistics sector. Any transport or logistics activity cannot go without human-being. The better the specialist meets the needs of the workplace, the easier it is for the company to integrate him into the transport/logistics process. Taking into account that industrial practice is an integral part of the specialist training process, the evaluation and the search of these practices become an important factor. On the other hand, corporate executives should be aware that industrial practices give the mutual benefit, for example: a young person who has joined the team can provide original thoughts, unusual and useful suggestions, and so on.

The aim of the article is to determine the impact of the organization and implementation of industrial practices on the preparation of young specialists in the transport and logistics sectors in the context of the concordance of self-actualization and study results.

Methodology:

- analysis of sources of literature;

- quantitative research;

- expert assessment.

\section{An analysis of industrial practices from a theoretical point of view}

The gap between the needs of specialists, their level of preparation and the organization of the study process is an essential problem facing both business enterprises and higher education institutions. There is also a major problem that the education and transport and logistics business sectors do not cooperate with each other. On the other hand, higher education schools often do not have such a substantive training base as the business has.

With the world becoming increasingly competitive as never before and less stable, companies operating in the logistics sector seek to gain a competitive advantage at any price, and focus more on the search for innovative resources, such as human resource practices (Sparrow et al. 1994). Since scientific literature does not provide any generally accepted concept of human resource management, there is also no consensus on what human resource practices actually are.

Human resource practices are defined in different aspects - Schuler and Jackson (1987) define them as a system, which attracts, develops, motivates and retains employees in order to ensure effective presence and perseverance of the organization and its members. Over the years, researchers offered many human resource practices, which may improve and maintain organizational efficiency. These practices cover focusing on employee selection based on internal culture of the company, also on their behaviour, attitude, technical skills necessary for the work that they do, activity-based remuneration, etc. It is also worth mentioning that authors have consistently gone towards the classification of human resources considering their primary impact on employee characteristics, which comes as a result of the qualification of human resource systems (Gardner 2005).

Human resource practices may affect the attitude of employees, encouraging them to work smarter and harder. This can be achieved using a compensation system as an incentive, also internal incentive systems, which are focused on employee merits, or other stimuli aimed at reconciling interests of the employer and shareholders. Bailey et al. (2000) observed that if the work performed by employees is structured and programmed, even highlyskilled and motivated employees can make a very limited contribution. This is due to the fact that even those employees, who know their work better than others, are unable to use their skills and abilities to create new or better methods for conducting their work. It is important to note than human resource practices can also affect activities conducted by the company via the regulations of the organizational structure, which encourage the engagement in work and allow them to improve their efficiency. Rotation, cross-functional groups or quality cycles may be examples of such a structure.

Minbaeva et al. (2003) examined human resource practices as a set of practices used in organizations in order to manage human resources creating more favourable conditions for the development of competencies of employees creating organizational knowledge in order to gain competitive advantage. In summary, the authors concluded that human resource practices are related to specific practices, formal policies and philosophies aimed at attracting, developing, motivating and retaining employees, who would ensure effective functioning and survival of the organization.

It is important to note that in early studies, authors were interested in human resource practice, which they called stand-alone, and the impact made by this practice on the overall activities of companies (Terpstra, Rozell 1993). The majority of empirical studies were focused on corporate practices rather than the research of the impact of individual practices. Two corporative approaches were prevalent at that time, namely, the interoperability and the systematic approach. The interoperability approach examines the impact of several practices of a company, meanwhile the systematic approach is focused on the examination of relative performance results of sets of all variables (Laursen, Foss 2012).

Despite numerous studies having examined human resource practices, there still is no consensus on the type of methods of human resources that best contribute to activities of the organization, as well as the preparation of a specialist and its adaptation in the labour market. 
It is important to note that previous studies observed that a greater focus on human resource practices may help reduce operating expenses in companies providing transport and logistics services.

Therefore, it is important to appreciate that industrial practice is an integral part of the quality of studies. Students improve their general and professional competences, become familiar with the peculiarities of production organization, and actually participate in the company's activities through practical training.

Practice models work best under general interest, i.e. when students, higher education institutions and businesses work closely together. However, in Lithuania, not all transport and logistics companies are willing to accept trainees and assign tasks according to the task set by the higher education institution (Ledauskaite, Štaraite 2013).

One of the main reasons why there are student placement difficulties is that there are too few state institutions that could organize student placements under the relevant field of study. In addition, they are not interested in such activities. Private companies are also often not interested in accepting students from higher education in practice placements either due to legal formalities or due to lack of motivation to do so (Ledauskaite 2010). Frequently, industrial practice is becoming more formal than the actual benefits for a trainee, an enterprise and the quality of studies.

\section{Assessment of the organization and implementation of industrial practices: a study of graduates' opinions}

A study, namely, a survey, was conducted 279 students, who had industrial practices in transport/logistics companies, took part in the survey. The aim of the study was to identify the companies where students have their industrial practices, the level of conformity of these industrial practices to the tasks of practice of schools of higher education, and the extent these industrial practices allow developing student competencies and ensuring their selfactualization.

The study identified that for the most part students completed their industrial practices in small or mediumsized enterprises (Figure 1).

Data received in the course of the study allow assuming that for the most part, small enterprises are not interested and/or do not have opportunities to admit students for industrial practices. On the other hand, clearing up the type of ownership of the company was important. The study allowed determining that private capital companies comprised the vast majority (87.82\%).

Students find the participation of a responsible company's person in the industrial practice process to be an important factor. Study results in this respect are very pleasing, because companies had appointed industrial practice supervisors for as many as $97.49 \%$ of students, which allows stating that companies treat apprentices with due responsibility. However, the fact that as many as $60.22 \%$ of the respondents were assigned assistant tasks only, and only $39.78 \%$ performed skilled work, which allowed deepening knowledge and acquiring the necessary skills for further activities, is disappointing.

Often students having performed well in their industrial practices were employed in large enterprises; however, only slightly more than $14 \%$ of trainees were employed in the course of their industrial practices, providing them with all social guarantees. However, paradoxically, out of $14.70 \%$ of the employed trainees, only $68.29 \%$ received a salary, accounting for a mere $10.04 \%$ of all respondents.

Given the fact that students find it important to deepen their knowledge acquired in higher education institutions in the course of their industrial practices, the study aimed to find out if trainees received the necessary information and what their opinion was thereof (Figure 2).

Figure 2 revealed that students had a positive opinion of the attention that they received. The respondents also assessed answers given to their questions related to the work performed during the industrial practice as very good (72.76\%) and good (25.45\%). However, the situation was different in the respondents' assessment of the conformity of the work performed by them in the course of their industrial practice to the study programme (Figure 3).

The study results revealed that students assessed the conformity of the work performed to the study programme as average, giving 3.85 points therefor. Assessment of conformity of goals and tasks of the work performed and the industrial practice rendered similar results (Figure 4).

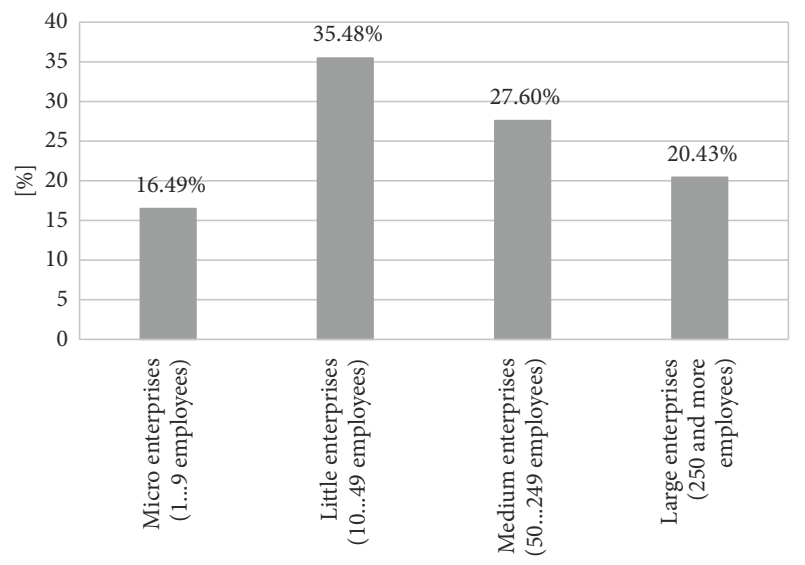

Figure 1. Distribution of companies by the number of employees

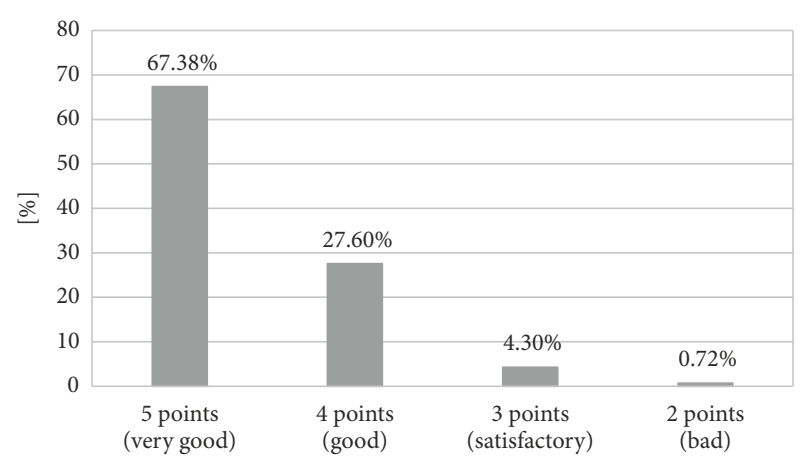

Figure 2. Assessment of attention of the employer or the company's industrial practice supervisor 
Figure 4 illustrates that students had a positive opinion of the conformity of the work performed to the goals and tasks of the industrial practice, giving 4.12 points on average. The usefulness of the acquired practical skills and knowledge received a slightly better assessment (Figure 5).

Figure 5 reveals that students assessed the usefulness of the acquired practical skills and knowledge sufficiently well, giving 4.48 points on average. Thus, the aim of the study was to find out what the respondents liked and what they did not like in their industrial practices.

The following is the list of things that they liked:

- respondents received a lot of practical knowledge, which helped them find a permanent employment;

- they liked to work and find out about work related to their specialty, see nuances of such work, which cannot be learnt from theoretical knowledge;

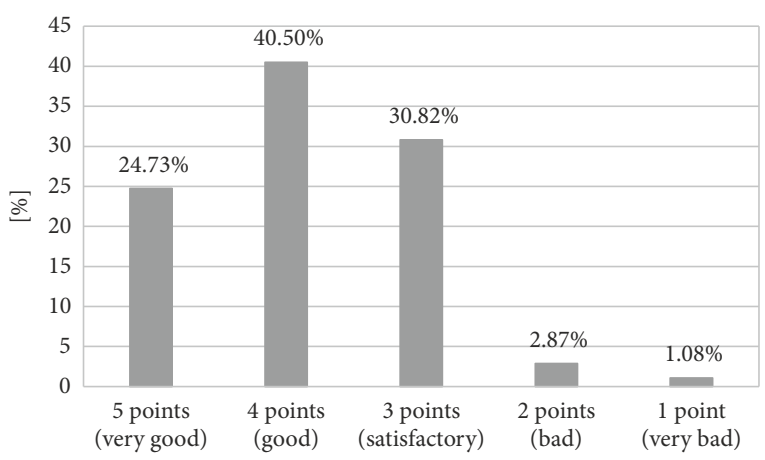

Figure 3. Assessment of conformity of the work performed during industrial practice to the study programme

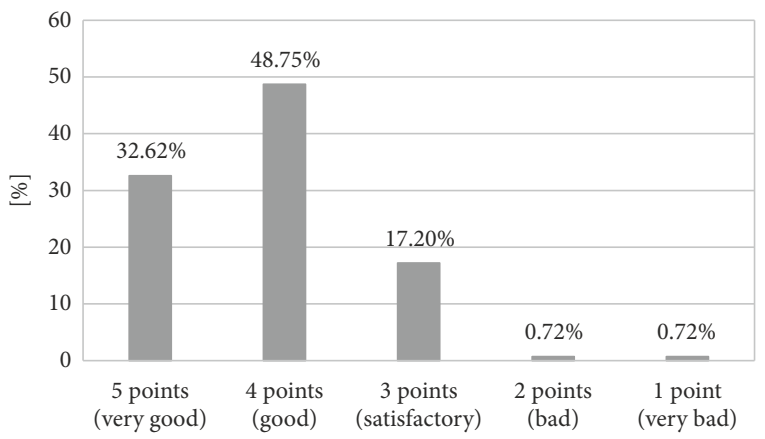

Figure 4. Assessment of conformity of the work performed to the goals and tasks of the industrial practice

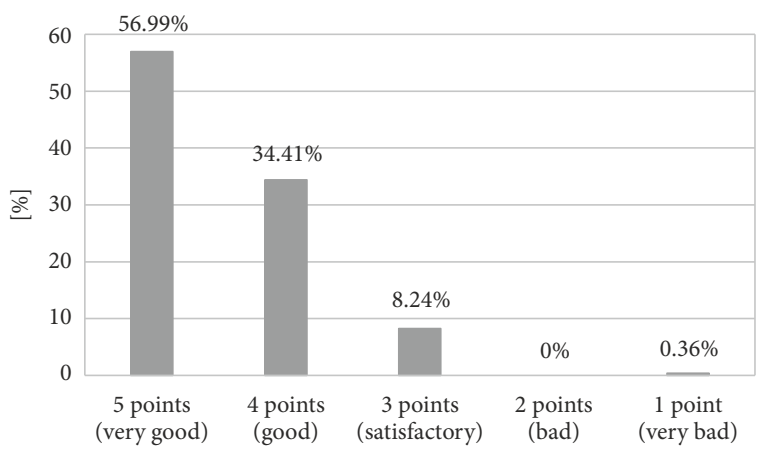

Figure 5. Assessment of usefulness of the acquired practical skills and knowledge
- they appreciated friendly and joyful team, the application and understanding of theoretical knowledge in practice, and a possibility to observe activities of co-workers;

- pleasant employees and their attention to the apprentice, the acquired knowledge, which improved understanding of the specifics of such work;

- opportunity to independently choose the placement for the industrial practice;

- Work was directly related to the object of learning;

- good team, cosy environment, prevailing democracy, employee diligence and responsibility;

- employer's attention, interesting work, application and understanding of theoretical knowledge in practice, an opportunity to observe activities of co-workers;

- all the opportunities for doing work where they could apply practical knowledge acquired during studies were provided;

- industrial practice supervisors were not afraid to assign tasks requiring sufficient responsibility;

- work was directly related to the object of learning;

- enjoyed work specifics itself, i.e. communication with customers, search for cargo, calculations.

The study identified that the main advantages were related to the attention shown to the trainee, assignment of tasks that require responsibility and an opportunity to see the specifics of work from inside. Unfortunately, respondents also named a number of things that they did not like in the course of their industrial practices:

- for the most part, work was supportive, not requiring responsibility at work;

- respondents wanted to work more with documents;

- monotony of the work performed and continuous work with personal computer;

- distrust in students, i.e. giving easy assignments or tasks that do not require much responsibility and are worthless;

- breaks between the tasks assigned;

- no salary paid for industrial practice.

In summary, it can be stated that students find working and finding out about work related to their specialty, also, discovering nuances of such work, which cannot be learnt through theoretical knowledge, to be very important. They liked the specifics of work itself, i.e. communication with customers, search for cargo, calculations. Good and friendly team at the work place, pleasant environment, prevailing democracy, employee diligence and responsibility, pleasant employees and their attention to trainee was also very important for the respondents. However, distrust in trainee and assignment of tasks that require little responsibility, which did not develop their skills and did not encourage their self-actualization, were identified as main drawbacks.

Having conducted the study, proposals may be made for the improvement of the industrial practice process:

- salary, even if it was minimal, should be paid for industrial practices; 
- students could be provided with an opportunity to have virtual industrial practices as a game, which would automatically help them improve;

- the duration of industrial practices should be longer, and account for about $40 \%$ of the total programme time, with theoretical studies accounting for $60 \%$;

- universities should reduce paperwork, simplify the industrial practice procedure and choose a more flexible time for industrial practices.

As per the above, the majority of the proposals are more focused on the organization of the industrial practice process, but there also were proposals targeted at financial issues, which is of particular relevance to the host institution rather than the school of higher education, which arranges industrial practices in enterprises.

\section{Assessment of the organization and implementation of industrial practice: expert research results}

One of the planned research methods is expert assessment method, which covers the surveying of experts by way of questionnaires as well as the assessment of the compatibility of expert opinions and the received results. Having conducted an expert survey, the coefficient of concordance was calculated according to the data received, which shows the level of compatibility of the group of experts.

A total of 12 teachers having long-term experience in the organization of industrial practices took part in the survey. The aim of the research of this part was to find out the problems, which are faced in the organization and implementation of industrial practices and the measures, which must be taken in order to receive the greatest effect for the improvement of competencies of trainee in the course of industrial practices, at the same time ensuring self-actualization of young specialists.

In the course of industrial practices, the fact that tasks performed at the time of the practice are not directly related to the goal and tasks of practice of schools of higher education is a frequent problem. Thus, during the research, respondents were asked to assess the extent that the work performed in the course of an industrial practice must correspond to the study programme and the task of practice of the school of higher education (Figure 6).

The research revealed that the majority of respondents believed that the work performed in the course of an industrial practice must conform to the study programme and the task of industrial practice of the school of higher education by at least $50 \%$, motivating that having a possibility to choose by themselves, students do not always manage to choose companies that conform to the industrial practice tasks by $100 \%$, while the host companies disregard the task of an industrial practice in order to meet their work needs, or disregard the issue altogether. Thus the aim of the research was to clear up the conformity of the goals of practices of schools of higher education to the work performed. The majority (66.67\%) of respondents noted that companies must consider both the goal and the tasks, while the remaining share (33.33\%) noted that it would be nice to have at least the goal of industrial practice taken into consideration. Such research results most probably are not random, because the content of industrial practices, just like the entire study process, is focused on certain study results. Thus, it is very important for the trainee to acquire the necessary knowledge and competencies related to study results and content of the programme during an industrial practice.

Another relevant issue is the appointment of a responsible person in companies and supervision over the trainee's work. Thus, the aim of the research was to find out who should devote the most attention to an apprentice and how much attention trainees should get (Figure 7).

During the research, respondents (100\%) noted that an industrial practice supervisor, who could show attention to the trainee and assign tasks considering the task and the content of the industrial practice as well as the needs of the enterprise, must be appointed in enterprises. This would lead to a better synergy and concordance of results as well as the conformity to study results. At the same time, the improvement of competencies and selfactualization of young specialists would be affected.

Considering the results of the above research of students and the fact that the respondents themselves named what was it that they did not like during their industrial practice, respondents were asked to rate (from the most to the least important) factors, which would allow achieving the maximum efficiency of industrial practices and would

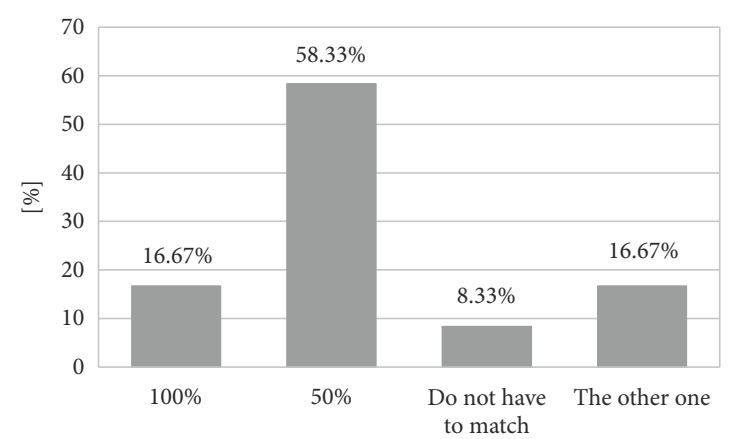

Figure 6. Consistency of the work performed in the course of an industrial practice with the study programme and the task of practice of the school of higher education

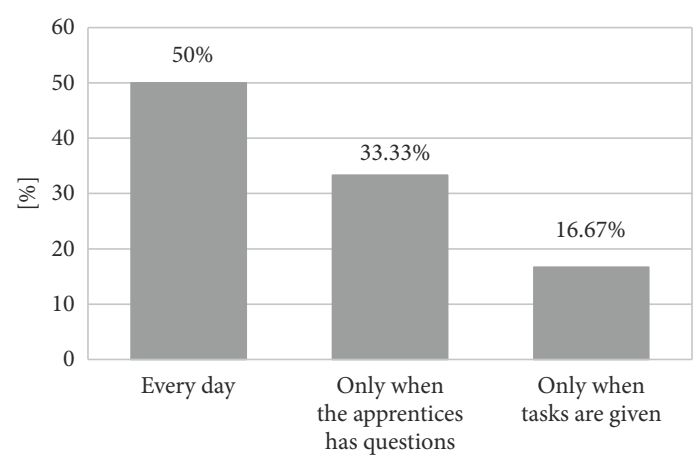

Figure 7. Frequency of attention that apprentices receive during industrial practice in an enterprise 
render a much greater effect for the improvement of competencies and self-actualization of young persons. Thus, respondents were asked to assess the presented factors. Data of questionnaires of twelve experts were randomly entered in Table 1.

Formula (1) is used to calculate the coefficient of concordance, when there are no associated ranks:

$$
W=\frac{12 \cdot S}{n^{2} \cdot\left(m^{3}-m\right)}=\frac{12 \cdot 2448}{12^{2} \cdot\left(7^{3}-7\right)}=0.6071 .
$$

The weight of the coefficient of concordance is calculated according to formula (2), and a random value is received:

$$
\begin{aligned}
& \chi^{2}=n \cdot(m-1) \cdot W=\frac{12 \cdot S}{n \cdot m \cdot(m+1)}= \\
& \frac{12 \cdot 2448}{12 \cdot 7 \cdot(7+1)}=43.7143 .
\end{aligned}
$$

The calculated $\chi^{2}$ value of 43.7143 is greater than the critical $\chi_{c r}^{2}$ value (equal to 12.5916); thus, the opinion of respondents is considered concordant, while average rankings show the general opinion of respondents:

$$
W_{\min }=\frac{\chi_{v, \alpha}^{2}}{n \cdot(m-1)}=\frac{12.5916}{12 \cdot(7-1)}=0.1749<0.6071 \text {. }
$$

The lowest value of the coefficient of concordance $W_{\min }$ was calculated according to the formula, stating that the opinions of all the 12 respondents about the 7 factors, which would result in the greatest effect on the improvement of competencies during industrial practices and ensure self-actualization of young specialists, are still considered concordant.

The indicators of importance $Q_{j}$ of factors that have the

\begin{tabular}{|c|c|c|c|c|c|c|c|}
\hline \multirow{2}{*}{ Respondent rank No } & \multicolumn{7}{|c|}{ Symbol of factor encryption $(m=7)^{\star}$} \\
\hline & $a$ & $b$ & $c$ & $d$ & $e$ & $f$ & $g$ \\
\hline$E_{1}$ & 7 & 6 & 3 & 1 & 2 & 5 & 4 \\
\hline$E_{2}$ & 7 & 5 & 3 & 4 & 1 & 6 & 2 \\
\hline$E_{3}$ & 7 & 5 & 3 & 4 & 1 & 6 & 2 \\
\hline$E_{4}$ & 7 & 6 & 3 & 4 & 5 & 2 & 1 \\
\hline$E_{5}$ & 7 & 5 & 3 & 4 & 6 & 2 & 1 \\
\hline$E_{6}$ & 7 & 6 & 2 & 1 & 3 & 5 & 4 \\
\hline$E_{7}$ & 7 & 6 & 3 & 4 & 5 & 2 & 1 \\
\hline$E_{8}$ & 6 & 7 & 3 & 1 & 5 & 2 & 4 \\
\hline$E_{9}$ & 6 & 7 & 3 & 1 & 5 & 2 & 4 \\
\hline$E_{10}$ & 7 & 6 & 3 & 1 & 2 & 5 & 4 \\
\hline$E_{11}$ & 7 & 5 & 3 & 4 & 6 & 2 & 1 \\
\hline$E_{12}$ & 7 & 6 & 2 & 1 & 3 & 5 & 4 \\
\hline$\sum_{i=1}$ & 82 & 70 & 34 & 30 & 44 & 44 & 32 \\
\hline $\bar{R}_{j}=\frac{\sum_{i=1} R_{i j}}{n}$ & 6,83 & 5.83 & 2.83 & 2.50 & 3.67 & 3.67 & 2.67 \\
\hline$\sum_{i=1}^{n} R_{i j}-\frac{1}{2} \cdot n \cdot(m+1)$ & 34 & 22 & -14 & -18 & -4 & -4 & -16 \\
\hline$\left(\sum_{i=1}^{n} R_{i j}-\frac{1}{2} \cdot n \cdot(m+1)\right)^{2}$ & 1156 & 484 & 196 & 324 & 16 & 16 & 256 \\
\hline \multicolumn{8}{|c|}{ 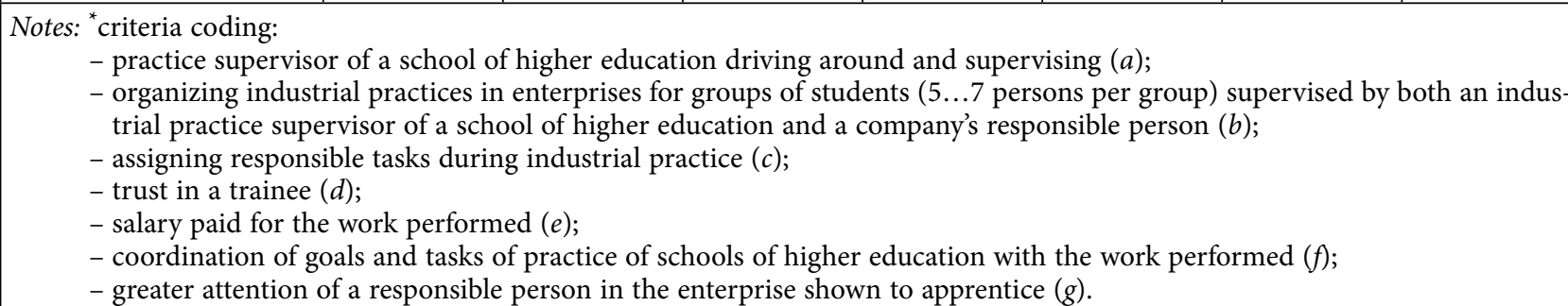 } \\
\hline
\end{tabular}
greatest effect on the improvement of competencies during industrial practices and assurance of self-actualization

Table 1. Table of the ratings received (source: compiled by the authors) 
of young specialists have been calculated. In order to calculate $Q_{j}$, at first $\bar{q}_{j}, d_{j}$ and then $Q_{j}$ are calculated. In addition, the importance of the quality criteria of the object evaluated by the experts in their normalization is determined by calculating the importance index of each criterion $Q_{j}^{\prime}$. The data received are presented in Table 2 .

Table 2 presents all the factors and their arrangement from the most to the least important.

According to respondents' assessments and the calculations made, the factors, which would result in the greatest effect on the improvement of competencies during industrial practices and ensure self-actualization of young specialists, should be implemented in the following sequence of priorities:

1) trust in the apprentice;

2) more attention of the company's responsible person shown to the trainee;

3) assignment of responsible tasks during industrial practice;

4) conformity of goals and tasks of the practice task of the school of higher education to the work performed;
5) salary paid for the work performed;

6) arrangement of industrial practices in enterprises for groups of students (5...7 persons per group) supervised by both the supervisor of practice of a school of higher education and a responsible person of the company;

7) practice supervisor of a school of higher education driving around and supervising over practices.

As per the research results, the best result may be achieved only when trainees are assigned responsible tasks and gets sufficient attention.

In summary, it can be stated, that in order to ensure the improvement of competencies of future specialists during industrial practices with the aim to ensure selfactualization of young specialists, the hypothetical model for the organization and implementation of the industrial practice process should be followed (Figure 8).

This model was drafted according to the described research results. The model also lists conditions for the organization and implementation of industrial practices, and possible results associable with the improvement of competencies, self-actualization of young specialists and

Table 2. Assessment of ratings (source: compiled by the authors)

\begin{tabular}{|l|c|c|c|c|c|c|c|c|}
\hline \multirow{2}{*}{$\begin{array}{c}\text { Indicator } \\
\text { sign }\end{array}$} & \multicolumn{7}{|c|}{ Symbol of factor encryption } & \multirow{2}{*}{ Sum } \\
\cline { 2 - 9 } & $a$ & $b$ & $c$ & $d$ & $e$ & $f$ & $g$ & \\
\hline $\bar{q}_{j}$ & 0.2440 & 0.2083 & 0.1012 & 0.0893 & 0.1310 & 0.1310 & 0.0952 & 1 \\
\hline$d_{j}$ & 0.7560 & 0.7917 & 0.8988 & 0.9107 & 0.8690 & 0,8690 & 0.9048 & 6 \\
\hline$Q_{j}$ & 0.1260 & 0.1319 & 0.1498 & 0.1518 & 0.1448 & 0.1448 & 0.1508 & 1 \\
\hline$Q_{j}^{\prime}$ & 0.0417 & 0.0774 & 0.1845 & 0.1964 & 0.1548 & 0.1548 & 0.1905 & 1 \\
\hline Factor ranking & 7 & 6 & 3 & 1 & 5 & 4 & 2 & \\
\hline
\end{tabular}

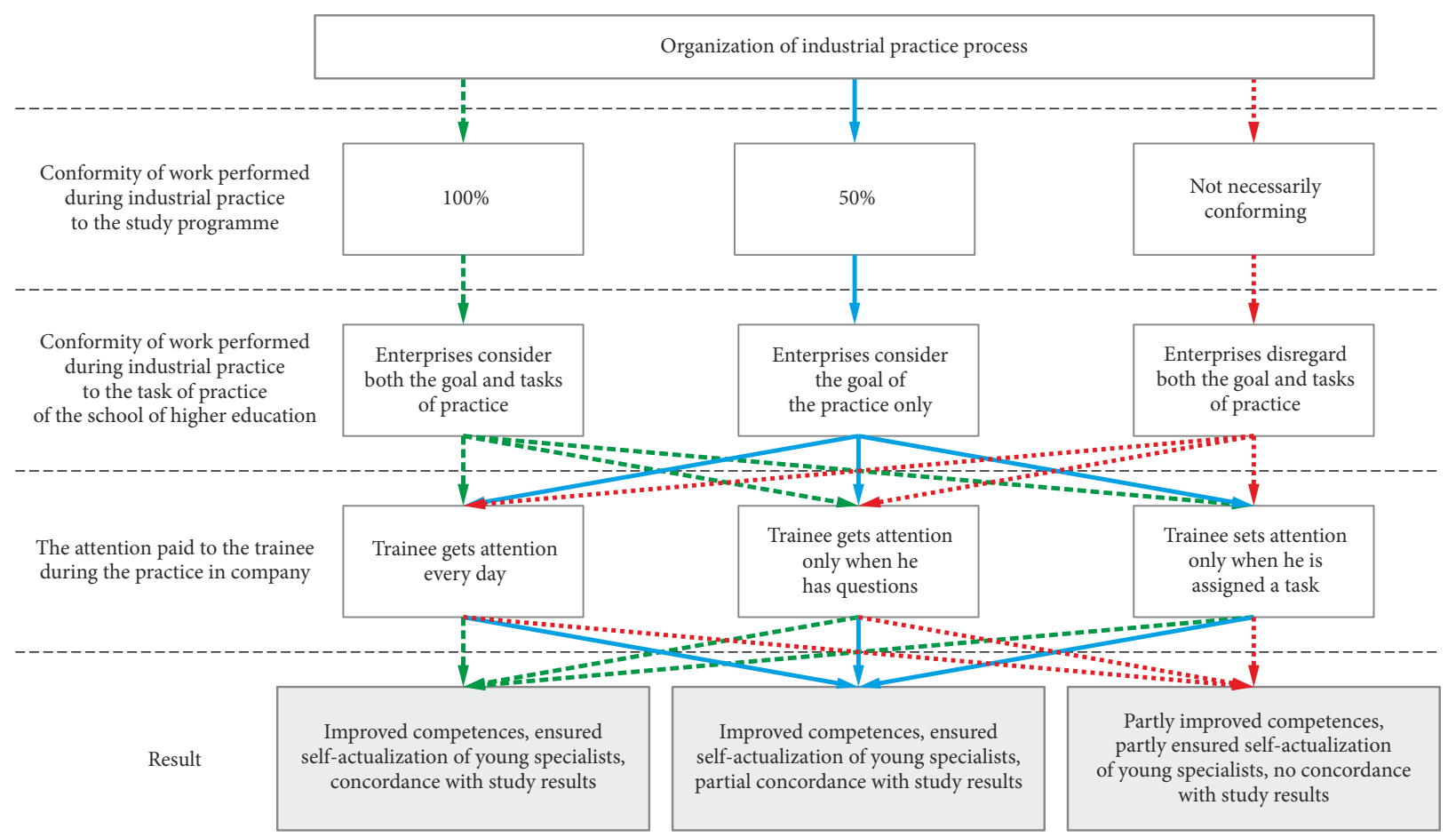

Figure 8. Hypothetical model for the organization and implementation of the industrial practice process 
concordance with study results. Thus, this model allows stating that solely a $100 \%$ conformity of work performed during the industrial practice to the study programme and the task of the practice of the school of higher education allows achieving the maximum result and the synergy. Otherwise, the future specialist for the labour market will only be partially prepared and the consensus with the study results will not be or will be only partially.

\section{Conclusions}

1) The examination of the sources of literature allows stating that human resource practices can affect activities conducted by the company via organizational structure regulations, which promote the engagement in work and allow them to improve their efficiency. It is important to note that a greater attention for human resource practices can help reduce operating expenses in companies providing transport and logistics services.

2) The research determined that the greatest advantages of industrial practices in transport/logistics companies are associated with the attention shown to trainees, assignment of responsible tasks and a possibility to see work specifics from inside. Students find it very important to work and to get familiar with specialty-related work, to see nuances of such work, which theoretical knowledge does not provide. Respondents also find good and friendly team at work, cosy environment, prevailing democracy, employee diligence and responsibility, pleasant employees and their attention to the trainee important.

3) Answers of respondents allow stating that a lot of practical knowledge was received in the course of industrial practices, which helped find a permanent employment. An opportunity to perform all tasks related to the work specifics of a logistics or a transport manager was provided during industrial practices, i. e. communication with clients, cargo search, selection of routes, etc.

4) Distrust in trainees and assignment of tasks that require little responsibility, which interferes with the development of competencies and encouragement of selfactualization, was identified as the greatest drawback of industrial practices.

5) Student responses revealed that the majority of proposals were targeted at the organization of the industrial practice process. But there also were proposals targeted at financial issues, which is most relevant to the host institution rather than the school of higher education, which arranges industrial practices in enterprises.

6) The $\chi^{2}$ value of 43.7143 calculated according to expert assessments is greater than the critical $\chi_{c r}^{2}$ value (equal to 12.5916); thus, the opinion of respondents is considered concordant, while average rankings show the general opinion of respondents.

7) According to respondent assessments and the calculations made, the following factors can be presented in priority order, which would render the greatest effect on the improvement of competencies during industrial practices and ensure self-actualization of young specialists:

- trust in trainees;

- more attention of a person responsible for trainees in the company;

- assignment of responsible tasks during industrial practices;

- concordance between the goals and tasks of the task of practice of the school of higher education with the work performed;

- salary paid for the work performed;

- arrangement of industrial practices in companies for student groups (5 ...7 persons per group), supervised by both an industrial practice supervisor of a school of higher education and a responsible person of the company;

- practice supervisor of a school of higher education driving around and supervising.

As per the research results, the best result may be achieved only when the trainee is assigned responsible tasks and gets sufficient attention.

8) The hypothetical model for the organization and implementation of the industrial practice process allows stating that in order to achieve the improvement of competencies, assurance of self-actualization of young specialists and concordance with study results, host companies must have a $100 \%$ consideration of study programmes of schools of higher education and the task of practice of schools of higher education, its goal and tasks. Thus, this model allows stating that the maximum conformity of the work performed during industrial practices to the study programme and the task of practice of schools of higher education allows achieving the best result and synergy.

\section{References}

Bailey, J. M.; Dunne, M. P.; Martin, N. G. 2000. Genetic and environmental influences on sexual orientation and its correlates in an Australian twin sample, Journal of Personality and Social Psychology 78(3): 524-536. https://doi.org/10.1037//0022-3514.78.3.524

Delery, J. E.; Doty, D. H. 1996. Modes of theorizing in strategic human resource management: tests of universalistic, contingency, and configurational performance predictions, Academy of Management Journal 39(4): 802-835. https://doi.org/10.5465/256713

Dessler, G. 2016. Human Resource Management. 15th edition. Pearson. 720 p.

Fisher, C. D.; Schoenfeldt, L. F.; Shaw, J. B. 2003. Human Resource Management. 5th edition. Boston Houghton Mifflin Co. 886 p.

Gardner, T. M. 2005. Interfirm competition for human resources: evidence from the software industry, Academy of Management Journal 48(2): 237-256.

https://doi.org/10.5465/amj.2005.16928398

Huselid, M. A. 1995. The impact of human resource management practices on turnover, productivity, and corporate financial performance, Academy of Management Journal 38(3): 635-672. https://doi.org/10.5465/256741 
Laursen, K.; Foss, N. J. 2012. Human Resource Management Practices and Innovation. SMG Working Paper No. 5/2012. 44 p. https://doi.org/10.2139/ssrn.2149464

Ledauskaitè, K. 2010. Transporto sektoriaus žmogiškuju ištekliu potencialo ekonominis vertinimas: daktaro disertacija. Vilniaus Gedimino technikos universitetas. 174 p. (in Lithuanian).

Ledauskaite, K.; Štaraite, E. 2013. Gamybinès praktikos - investicija ị verslo ateiti, iš Studijos besikeičiančioje verslo aplinkoje: respublikinès mokslinès-praktinès konferencijos, įvykusios Alytaus kolegijoje $2013 \mathrm{~m}$. balandžio 19 d., pranešimu medžiaga, 118-123. (in Lithuanian).

Minbaeva, D.; Pedersen, T.; Björkman, I.; Fey, C. F.; Park, H. J. 2003. MNC knowledge transfer, subsidiary absorptive capacity, and HRM, Journal of International Business Studies 34(6): 586-599. https://doi.org/10.1057/palgrave.jibs.8400056

Noe, R.; Hollenbeck, J.; Gerhart, B.; Wright, P. 2016. Human Resource Management: Gaining a Competitive Advantage. 10th edition. McGraw-Hill Education. 768 p.

Price, A. 2007. Human Resource Management in a Business Context. 3rd edition. Cengage Learning Business Press. 672 p.

Schuler, R. S.; Jackson, S. E. 1987. Linking competitive strategies with human resource management practices, Academy of Management Perspectives 1(3): 207-219. https://doi.org/10.5465/ame.1987.4275740

Sparrow, P., Schuler, R. S.; Jackson, S. E. 1994. Convergence or divergence: human resource practices and policies for competitive advantage worldwide, The International Journal of Human Resource Management 5(2): 267-299. https://doi.org/10.1080/09585199400000019

Terpstra, D. E.; Rozell, E. J. 1993. The relationship of staffing practices to organizational level measures of performance, Personnel Psychology 46(1): 27-48. https://doi.org/10.1111/j.1744-6570.1993.tb00866.x

Torrington, D.; Hall, L.; Taylor, S.; Atkinson, C. 2010. Human Resource Management. 8th edition. Financial Times/Prentice Hall. 848 p. 